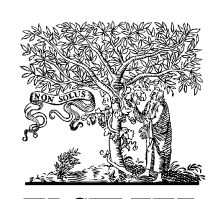

ELSEVIER

\title{
The fossil record of South American short-faced bears (Ursidae, Tremarctinae)
}

\author{
Leopoldo H. Soibelzon*, Eduardo P. Tonni, Mariano Bond \\ Departamento Científico Paleontología de Vertebrados, Museo de La Plata. Paseo del Bosque, (1900) La Plata, Buenos Aires, Argentina
}

Received 1 April 2003; accepted 2 July 2005

\begin{abstract}
The present study includes a review of the geographic and stratigraphic distribution of short-faced bears (Ursidae, Tremarctinae) in South America. In addition, the authors discuss biogeographic hypotheses regarding the origin of South American tremarctines. The Tremarctinae subfamily is distributed exclusively in America, from Alaska to southern Patagonia. Its biochron comprises the temporal lapse between Late Miocene and recent times; the first record of Tremarctinae in North America corresponds to the Hemphillian and the last to the Rancholabrean. In South America, the first record corresponds to the Ensenadan. In the present day, it corresponds to the only living tremarctine, the 'Andean Bear,' but short-faced bears became extinct during the early Holocene. The extinction of short-faced bears in North and South America appears to have been approximately synchronous. Finally, the fossil record in South America indicates species turnover between the Ensenadan and Bonaerian, during which time the giant species Arctotherium angustidens was replaced by Arctotherium tarijense, Arctotherium bonaeriense, and Arctotherium vetustum (and probably Arctotherium wingei).
\end{abstract}

(C) 2005 Elsevier Ltd. All rights reserved.

Keywords: Biostratigraphy; Short-faced bears; South America

\section{Introduction}

The bear genera that constitute the subfamily Tremarctinae (Carnivora: Ursidae) are distributed exclusively in America. Of these, (1) Plionarctos Frick is recorded from the Late Miocene to the Early Pliocene of North America with two species, $P$. edensis Frick and $P$. harroldorum Tedford and Martin; (2) Arctodus Leidy contains two North American Late Pliocene and Pleistocene species, A. pristinus Leidy and A. simus (Cope); (3) Arctotherium Burmeister comprises five South American species: A. angustidens Gervais and Ameghino, which is restricted to the Ensenadan (Early-Middle Pleistocene), A. vetustum Ameghino, registered only in the Bonaerian (Middle Pleistocene), and three Bonaerian and Lujanian (Middle Pleistocene-Early Holocene) species, A. wingei Ameghino, A. bonariense (Gervais), and A. tarijense Ameghino (Soibelzon, 2004); and (4) Tremarctos Gervais includes

\footnotetext{
* Corresponding author.

E-mail address: 1soibelzon@fcnym.unlp.edu.ar (L.H. Soibelzon).
}

0895-9811/\$ - see front matter (C) 2005 Elsevier Ltd. All rights reserved. doi:10.1016/j.jsames.2005.07.005 two species, T. floridanus (Gildey) from the Late Pliocene and Pleistocene of North America and the only living Tremarctinae, T. ornatus (Cuvier) of South America, which has not been recorded as a fossil. The Tremarctinae are a monophyletic group; Ursinae is their sister group (Trajano and Ferrarezzi, 1994; Talbot and Shields, 1996). Plionarctos and Tremarctos constitute the 'spectacled bears' clade, a basal group of the Tremarctinae, and Arctodus and Arctotherium conform to the 'short-faced bears' clade. Within the clade formed by the Arctotherium species, $A$. vetustum and $A$. wingei are more primitive than A. angustidens. Finally, A. bonariense and A. tarijense are the most derived species (Soibelzon, 2002).

This study includes a review of the geographic and stratigraphic distribution of short-faced bears in South America. In addition, we discuss the biogeographical hypotheses of Ameghino (1885, 1906), Kraglievich (1926), Trajano and Ferrarezzi (1994), and Cartelle (1998) regarding the origin of South American tremarctines.

The abbreviations we use herein are as follows: AMNH, American Museum of Natural History, USA; BMNH, Natural History Museum, UK; CM, Carnegie Museum, USA; GALY, collection of the 'Grupo de Arqueología' of 
Liceo Young, República Oriental del Uruguay; GP, Museu Paulista, Universidad de San Pablo, Brazil; FLMNH, Florida Museum of Natural History, USA; IGC, Instituto de Geociencias de la Universidad Federal de Minas Gerais, Brazil; MACN, Museo Argentino de Ciencias Naturales 'Bernardino Rivadavia', República Argentina; MACN zool, Colección del Departamento de Mastozoología del MACN, República Argentina; MCA, Museo Carlos Ameghino, República Argentina; MHJ, Museo Histórico de Junin, República Argentina; MHN, Museu de Historia Natural de la Universidad Federal de Minas Gerais, Brazil; MLP, Colección del Departamento Científico Paleontología de Vertebrados, Museo de La Plata, República Argentina; MLP (DZV), Colección del Departamento Científico Zoología de Vertebrados, Museo de La Plata, República Argentina; MMCN, Museo Municipal de Ciencias Naturales 'Monte Hermoso', República Argentina; MMMP, Museo Municipal de Mar del Plata 'Lorenzo Scaglia', República Argentina; MMPH, Museo Municipal 'Punta Hermengo', República Argentina; MNHN PAM, Museum National d'Histoire Naturelle, Paris, Colección del Pampeano, France; MPV, Museo Paleontológico de Valencia, España; MST, Museo 'Sueño del Tano', República Argentina; PMUZ, Paläontologische Institut und Museum der Universität Zürich, Switzerland; UF, University of Florida, USA; UMAG, Universidad de Magallanes, Chile; and UZM, Zoological Museum, University of Copenhagen.

\section{Material and methods}

For a detailed list of the stratigraphic and geographic provenances of each sample of material, see Soibelzon (2002; 2004).

A. vetustum. MACN A1277, type of A. vetustum, Villa Urquiza, Entre Ríos province, Middle-Late Pleistocene. Referred material: Argentina, Buenos Aires province, Mercedes: MACN 1201 (Bonaerian, Middle Pleistocene). Coronel Pringles: MMMP 1233M (Bonaerian [Berman, 1994]). Río Arrecifes: MLP 10-7 (Bonaerian; see Soibelzon et al., 1999). Entre Ríos province, Arroyo Alcaraz: MACN 17486 (Middle-Late Pleistocene).

A. vetustum? Brazil, Bahia state, Minas Gerais: MHN s/n (see the skull in Cartelle, 1994).

A. wingei. MACN 1453, type of A. wingei from Tarija Valley, Bolivia, Pleistocene. UZM 5249, 5715, 5717, 572122, and 5723; types of 'Ursus brasiliense' from several caves in Lagoa Santa region, Brasil (see Winge, 1895-1896). Referred material: Brazil, Minas Gerais state, Lapa da Escrivania N5: MACN 6273. Ceará state, Ubajara: GP/2-T4 (out of stratigraphic context; see Trajano and Ferrarezzi, 1994). Bahía state, Campo Formoso: IGC 10 (out of stratigraphic context, see Cartelle, 1998). Bolivia, Tarija County, Tarija Valley: MACN 1454 (Pleistocene). Venezuela, Falcon state, 'El Muaco' local fauna: \#1 (Late Pleistocene; Linares, pers. comm.). Monagas state, 'Cueva del Guácharo' local fauna: \#2 (Early Holocene, Linares, pers. comm.).

A. angustidens. BMNH 32915-16, 32971-72, 32969, and 32974-91, type of A. angustidens from 'Toscas del Río de La Plata,' Buenos Aires province; Ensenadan. MACN 43, type of 'A. latidens' from 'Callejón de Ibáñez' Buenos Aires; Ensenadan (Early-Middle Pleistocene). MACN 5132, type of 'A. candiotti' from an excavation in Buenos Aires City; Ensenadan. Referred material: All the material listed next are from the Ensenadan, Argentina, Buenos Aires province, Toscas del Río de La Plata: MACN 851, 972, 974, 1202, 1892, 13265, 16260, 1926, 1994, 1997, 2011, 2020, 2024, 2158, 2178, 2179, 2536, 2547, 2548, 3158, 5702, $5705,6222,6223,8262,8791,8792,8794,9609,10094$, 10459, 2275, 2297, 5690, 5696, 8691, 8700, 10458, and 18008; MLP 99-X-5-1, 82-X-22-1, and 99-X-3-1. La Plata: MLP 35-IX-26-3/6, 39-IV-21-1, and 58-X-4-1. Moreno: MACN 17719. Buenos Aires City: MACN 12529, MNHN PAM 179, Paleontological Collection of Museo Miguel Lillo, Tucumán s/n. Mar del Plata City: MMMP 1232. Mar del Plata marine cliff: MMMP 26S and 162S; MMMP 48S; MACN 17986. Gorina: MLP 68-V-26-1 and 97-I-5-1. Ezeiza: MLP 00-VII-10-1. Ezpeleta: MLP 00-VII-15-1. Vivoratá: MMMP 3980, 3981, and 3982. San Pedro: MLP 97-II-2-1, MST P2 99-IX-15. Campana: MPV 613 and 614. Miramar: MLP 01-IV-1-1 and 87-V-5-1. Mar del Sur: MMPH 018. Río Pergamino: PMUZ 45. Bolivia, Tarija, Tarija Valley: AMNH 117433.

A. bonariense. MNHN PAM 264, type of Ursus bonariensis from an undetermined site around Luján City (see Gervais, 1855; Soibelzon, 2002; 2004), Buenos Aires province, Middle-Late Pleistocene (Lujanian?). MACN 2668, type of 'Pararctotherium enectum' from an excavation at the corner of Cangallo and Cerrito streets in Buenos Aires City; Early Bonaerian. MACN 9646, type of 'Pararctotherium pamparum crassidens' from Río Quequén Salado; Lujanian. Referred material: Argentina, Buenos Aires province, Río Quequén Salado: MACN 9645 and 9647, MMCN 69-6-1 (Lujanian). Necochea: MACN 13971 (Pleistocene). Roque Pérez: MACN 14614 (Bonaerian). Mar del Plata marine cliff: MLP 99-X-10-1 (Early Bonaerian).

A. tarijense. MACN 1458, type of A. tarijense from Tarija Valley, Bolivia; Pleistocene. MACN 2667, type of 'Paractotherium enectum' from an excavation in Buenos Aires City; Early Bonaerian (see Ameghino, 1904). MACN 971, type of 'Pararctotherium pamparum' from Mercedes, Buenos Aires province; Late Bonaerian (see Ameghino, 1904). Referred material: Argentina, Buenos Aires province, Dolores: MACN 8581 and 8582 (Lujanian). Luján: MACN 2180 (Late Lujanian). Río Salto: MCA 1087 (Bonaerian). Río Arrecifes: MLP 10-71 (Bonaerian). Mar Chiquita: MLP 92-XI-28-1. Centinela del Mar: MLP 92-XI27-1 (Early Lujanian). Junín: MHJ 544 (Late Lujanian). Mar del Plata City: MMMP 1441(Late Lujanian). Santa Fé Province, Grütly: MLP 34-VIII-1-1 (Bonaerian). Uruguay, 


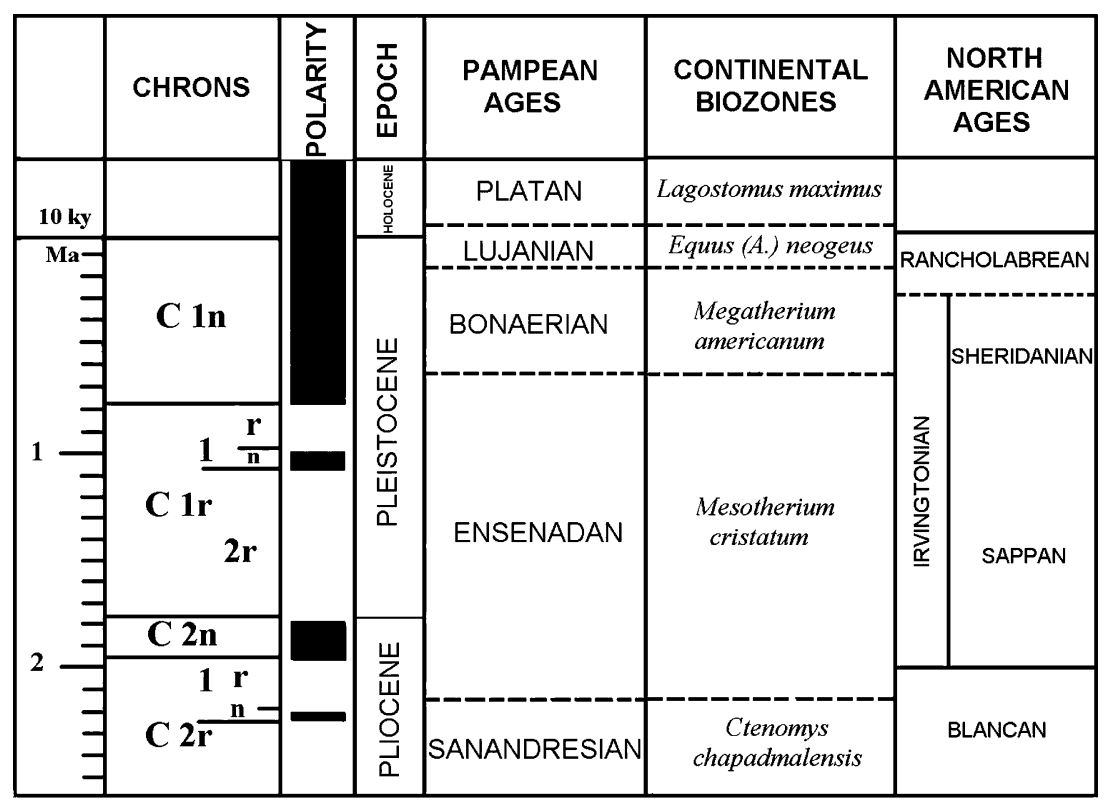

Fig. 1. Chronological chart of the late Cenozoic in South America (modified from Cione and Tonni, 1999).

Río Negro County: GALY s/n (Late Lujanian). Chile, Magallanes County, Pali Aike National Park: UMAG 53643 (Late Lujanian).

Arctotherium sp. Argentina, Buenos Aires province: MACN 12654. Tapalqué: MLP 10-70 (Bonaerian). Santa Fe Province, Río Carcarañá: MACN 11443 (Pleistocene). San Luis Province, Las Lagunitas: MACN 12558 (Pleistocene).

In discussing this record, we rely greatly on the biostratigraphic record of the Pampean area of central Argentina, the best known in South America (see Tonni and Cione, 1999; Cione and Tonni, 1999; 2001; Fig. 1). Cione and Tonni (1999, 2001) consider the Tolypeutes pampaeus biozone the biostratigraphical base of the Ensenadan; however, Tolypeutes pampaeus could be a poorly defined species, and its temporal range could be wider than the Ensenadan (Carlini and Scillato-Yané, pers. comm.). Therefore, we propose a new taxon to define this biozone: Mesotherium cristatum, a well-defined, frequent, geographically widely distributed notungulate restricted to the Ensenadan (Bond, 1999).

\section{Introduction to the fossil record of Tremarctinae}

\subsection{Geographic and stratigraphic distribution}

The Tremarctinae biochron comprises the temporal lapse between the Middle Hemphillian (earliest Late Miocene) and the present (Fig. 2).

In North America, they are recorded from the earliest Late Miocene to the Early Holocene; the oldest record of a Tremarctinae bear (Plionarctos sp.) comes from the Middle Hemphillian (Tedford and Martin, 2001). P. edenensis is recorded in the Late Hemphillian and $P$. harroldorum in the Blancan I (Early Pliocene; Tedford and Martin, 2001). Plionarctos has not been recorded in sediments younger than Early Pliocene; Tremarctos is recorded from the Blancan III (Late Pliocene) to the present; T. floridanus appears from the Blancan III to the Rancholabrean (MiddleLate Pleistocene); and T. ornatus only occurs in present times (Kurtén, 1966). The oldest record for Arctodus is Blancan IV (Latest Pliocene), and the youngest is Rancholabrean. The biochron of $A$. pristinus comprises the temporal lapse between the Blancan IV and Irvingtonian (Early-Middle Pleistocene); that of $A$. simus comprises the temporal lapse between the Irvingtonian and Rancholabrean (Kurtén, 1967). In North America, the youngest records emerge for A. simus $\left(9630 \pm 60{ }^{14} \mathrm{C}\right.$ yr BP, Gobetz and Martin, 2001; 10,800 ${ }^{14} \mathrm{C}$ yr BP, Gillette, 1996) and $T$. floridanus $\left(10,500{ }^{14} \mathrm{C}\right.$ yr BP, Anonymous, 1998; $7432 \pm$ $300{ }^{14} \mathrm{C}$ yr BP [C-823]).

In South America, the oldest records of fossil bears are Ensenadan, the 'Puelchan' record could be Ensenadan in age (Cione and Tonni, 1995), and the youngest are latest Lujanian (Early Holocene). According to ${ }^{14} \mathrm{C}$ dates, the two youngest records in South America are A. tarijense (UMAG 53643, 11,210 $\pm 50{ }^{14} \mathrm{C}$ yr BP, San Roman et al., 2000; GALY s/n, $11,600 \pm 130{ }^{14} \mathrm{C}$ yr BP, Ubilla and Perea, 1999). In addition, the only existing extant Tremarctinae (Tremarctos ornatus) lives in South America.

\subsection{Geographic distribution}

The subfamily Tremarctinae is distributed exclusively in America, from Alaska to southern Patagonia. The UMAG 53643 at 'Cueva de los Chingues,' Chile (Prevosti et al., 2003) is the southernmost record of Ursidae in the world. 


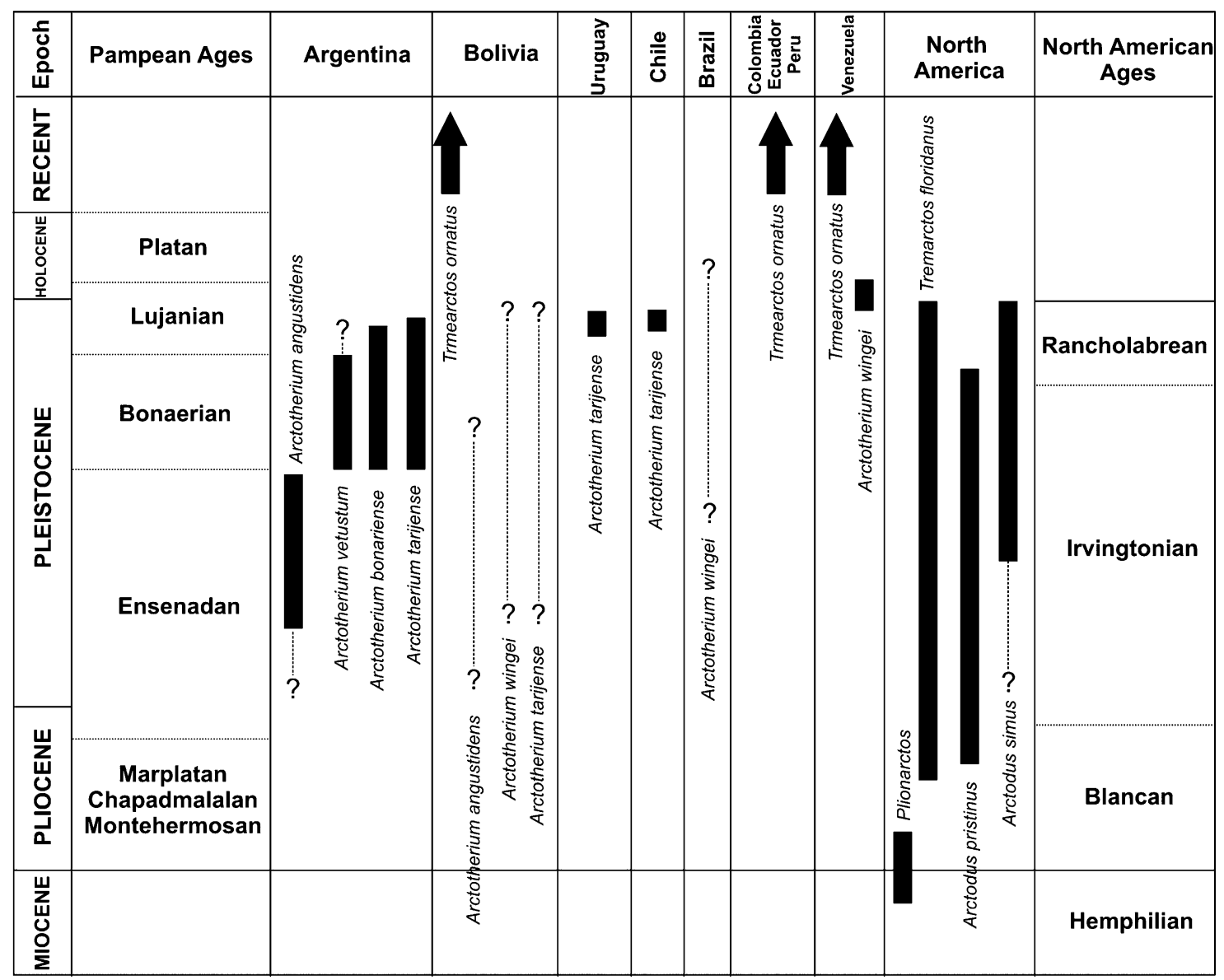

Fig. 2. Chronological chart of the late Cenozoic in North and South America showing the Tremarctinae biochrons (modified from Soibelzon, 2002).

In North America, Plionarctos is recorded in the central western area, and Tremarctos floridanus appears in the southern area. Arctodus presents the widest distribution of the North American taxa (Kurtén, 1966, 1967; Kurtén and Anderson, 1980; Soibelzon, 2002).

In South America, Arctotherium is recorded mainly on the east side of the continent from Venezuela to southern Patagonia (Venezuela, Brazil, Uruguay, Argentina, Bolivia, and Chile), whereas Tremarctos ornatus is distributed on the west (Venezuela, Colombia, Ecuador, Peru, and Bolivia).

\section{The fossil record of short-faced bears in South America}

\subsection{Temporal distribution}

The fossil record in South America usually presents serious problems because it often lacks sufficient documentation of the stratigraphic and/or geographic provenance of materials from old collections, such as those from MiddleLate Pleistocene sediments (late Pampean sediments). In some localities, one of the authors (EPT) was able to use the well-known stratigraphy as documentation. Although for some remains, the stratigraphic reassessment provided additional information, for in another 10-15 records, it was impossible to assess the stratigraphic position.

\subsubsection{Ensenadan}

The M. cristatum biozone represents the Ensenadan in the Pampean region (Tonni and Cione, 1999; Fig. 1). During the Ensenadan, only one bear species, the gigantic $A$. angustidens, is recorded. For a detailed discussion of the Ensenadan record of short-faced bears, see Soibelzon et al. (2001); Soibelzon (2002; 2004).

The primary, and oldest, record of A. angustidens comes from the Toscas del Río de La Plata. This level corresponds to chron C1r2r (Tonni et al., 1999). According to the available magnetostratigraphic information, the age of the Toscas del Rìo de La Plata is older than $0.98 \mathrm{Ma}$ and younger than 1.76 Ma (Bidegain, 1991; Tonni et al., 1999).

Some specimens of $A$. angustidens were found in the marine cliff from southeastern Buenos Aires province. Three specimens (MMMP 162S, 26S, 48S) came from these marine cliffs north of Mar del Plata City. In this area, sediments have been referred to the Ensenadan, Bonaerian, Lujanian, and Platan (Tonni et al., 1992; Cione and Tonni, 1995; 1999). Recent magnetostratigraphic studies by Bidegain et al. (1998) show that a change from chron C1r to $\mathrm{C} 1 \mathrm{n}$ can be identified $7 \mathrm{~m}$ above the top of the cliff $(3 \mathrm{~m}$ 
from the base). This finding implies that the age of the sediments where MMMP 26S and 48S were found is $0.98-$ $0.78 \mathrm{Ma}$. Unfortunately, the stratigraphic procedure used for MMMP $162 \mathrm{~S}$ is not precise ('middle part of the cliff'); therefore, the sediments to which it has been referred could pertain to chron $\mathrm{C} 1 \mathrm{r}$ or the base of chron $\mathrm{C} 1 \mathrm{n}$. If so, the age of the sediments could be younger than $0.78 \mathrm{Ma}$.

Approximately $50 \mathrm{~km}$ south of Mar del Plata City, at the D level of the marine cliff 'Punta Hermengo' (Tonni and Fidalgo, 1982), two specimens (MLP 87-V-5-1 and MLP 01-IV-1-1) were found. No magnetoestratigraphic information exists for this sector of the marine cliff, though Tonni et al. (1998) correlated the D level with the lower to middle section of the northern marine cliff at Mar del Plata City on the basis of the faunistic record. In the B level (Soibelzon and Soibelzon, 1999), at the base of the marine cliff $5 \mathrm{~km}$ south of Mar del Sur, MMPH 18 was found. Soibelzon et al. (2001) correlated this level with the lower to middle section of the northern marine cliff at Mar del Plata City.

Several records of $A$. angustidens were found in Tarija Valley (e.g. AMNH 117433 and others housed in museums in La Paz and Tarija, Bolivia), but none contains indicators about the stratigraphic provenance. The Tolomosa (formerly Tarija) Formation is composed of two units: The lower one consists of poorly fossiliferous clays, and the highly fossiliferous upper one is composed of conglomerates. The age of the base of the lower unit is approximately $1 \mathrm{Ma}$ (MacFadden, 2000). Thus, the lower unit could be regarded as Ensenadan in age, though not by its biostratigraphical context. It is noteworthy that the highly fossiliferous upper unit is younger than $0.78 \mathrm{Ma}$. Thus, the specimens of A. angustidens found in Tarija may be Ensenadan in age, according to the record of this species in the Pampean region of Argentina.

In summary, A. angustidens is not very frequently recorded (similar to other members of Carnivora) but represents a conspicuous element of the $M$. cristatum biozone. Furthermore, A. angustidens is a characteristic species of the Ensenadan, and its biochron comprises the temporal lapse between $1.76 \mathrm{Ma}$ (chron C1r2r) and $0.78 \mathrm{Ma}$ (base of chron C1n) (Soibelzon et al., 2001).

\subsubsection{Bonaerian}

The Megatherium americanum biozone corresponds to chron $\mathrm{C} 1 \mathrm{n}$ and represents the Bonaerian in the Pampean region (Tonni and Cione, 1999; Fig. 1). The records of $A$. vetustum, $A$. bonariense, and $A$. tarijense start in the Bonaerian (Soibelzon, 2002), as do many other clades of holartic origin that demonstrate a great increase in diversity (Cione and Tonni, 2001).

In sediments assigned to the Early Bonaerian at Buenos Aires City (Ameghino, 1904), A. tarijense (MACN 2667) and $A$. bonariense (MACN 2668) have been recorded. In sediments of the marine cliff outcropping $500 \mathrm{~m}$ south of 'Parque Camet' (north of Mar del Plata City), A. bonariense
(MLP 99-X-10-1) was found and assigned to the Early Bonaerian (Soibelzon et al., 2001). A. tarijense (MACN 971) and $A$. vetustum (MACN 1201) were recorded in the Late Bonaerian of Mercedes (Buenos Aires province; Ameghino, 1904).

In the Bonaerian s.l., both A. vetustum (MMMP 1233, Galileo Scaglia in Berman, 1994; MLP 10-7, Soibelzon et al., 1999) and A. tarijense (MLP 10-71, Soibelzon et al., 1999; MCA 1087, MLP 34-VIII-1-1) were recorded. Two other specimens of A. vetustum are recorded in Entre Rìs province (MACN A1277 from Villa Urquiza and MACN 17486 from Arroyo Alcaraz); because they lack stratigraphic information however, they can be confidently assigned only to the Middle-Late Pleistocene.

In summary, evidence indicates that $A$. vetustum is recorded exclusively in the Bonaerian, at least in the Pampean area. The likely record of A. vetustum in Brazil remains to be confirmed from a taxonomic point of view. Also, the fossil records of $A$. tarijense and A. bonariense start in the Bonaerian, at least in the Pampean area of Argentina.

\subsubsection{Lujanian}

The Equus (Amerhippus) neogeus biozone represents the Lujanian in the Pampean region (Tonni and Cione, 1999; Fig. 1). This biozone corresponds to chron C1n, as well as the Bonaerian. From the Lujanian, three species have been recorded: A. wingei, A. bonariense, and A. tarijense.

The only species recorded in sediments that represent the Early Lujanian ( $130 \mathrm{ka}$, Isla et al., 2000) is A. tarijense (MLP 92-XI-27-1), from the marine cliff at Centinela del Mar, Buenos Aires province.

At Río Quequèn Salado (Buenos Aires province), both $A$. bonariense (MACN 9645-47 and MMCN 69-6-1) and Arctotherium sp. (MLP 42-VI-24-29) were recorded. On the flow plain of Río Quequèn Salado, sediments represent the temporal lapse between approximately $130 \mathrm{ky}$ and 1210 ky BP (Pardiñas et al., 1996).

From the Late Lujanian ( $20 \mathrm{ky}$, Tonni et al., 1998) of southern South America, only one species, A. tarijense, is recorded. Specimen MLP 92-XI-28-1 comes from the marine cliff at Camet Norte, where sediments have been dated 24,450 $\pm 150{ }^{14} \mathrm{C}$ yr BP (Pardiñas et al., 1998). Specimen MMMP 1441 comes from an excavation in Mar del Plata City whose sediments have been assigned to the Late Lujanian (G. Scaglia in Berman, 1994). From an auxiliary channel of Río Salado, $6 \mathrm{~km}$ southwest of Junìn (Late Lujanian, De Salvo et al., 1969) comes specimen MHJ 544. Finally, also from the Late Lujanian and near Luján City, specimen MACN 2180 was recovered.

The two youngest records of fossil bears in southern South America correspond to A. tarijense. The youngest (UMAG 53643; Prevosti et al., 2003) comes from 'Cueva de los Chingues' (Pali Aike National Park; 52 $05^{\prime} 37^{\prime \prime} \mathrm{S}$, $69^{\circ} 44^{\prime} 31^{\prime \prime} \mathrm{W}$, Magallanes County, Chile) and has been dated as $11,210 \pm 50{ }^{14} \mathrm{C}$ yr BP (San Roman et al., 2000). 
The other young specimen (GALY s/n; cited as 'Pararctotherium pamparum' by Perea and Ubilla, 1983; see Soibelzon, 2002) is from Río Gutiérrez, Río Negro County, Uruguay, and has been dated as $11,600 \pm 130{ }^{14} \mathrm{C}$ yr BP (Ubilla and Perea, 1999).

Also during the Late Lujanian but in northern South America, A. wingei has been recorded (\#1 from 'El Muaco' local fauna, Falcón state, Venezuela; \#2 from 'El Guácharo' cave local fauna, Monagas state, Venezuela; Linares, pers. comm.). These two are the only records for $A$. wingei that contain a stratigraphic provenance, but there are no ${ }^{14} \mathrm{C}$ data for them. As we emphasized previously, it is impossible to determine the biochron of $A$. wingei because only these two individuals have stratigraphic information. Other samples of the species lack precise indicators (e.g. MACN 1453 and 1454 from Tarija Valley, Bolivia) or were found out of their stratigraphic context in caves such as Lagoa Santa (e.g. UZM 5249, 5715, 5717, 5721-22, 5723) or others in Brazil (e.g. GP/2-T4; IGC 10). Thus, it is not possible to establish the biochron of $A$. wingei with precision, though Trajano and Ferrarezzi (1994); Cartelle (1998) believe the specimens came from the Late Pleistocene $(\sim 12 \mathrm{ka}$.)

In summary, A. wingei is recorded exclusively in the Lujanian, but more records are needed to confirm this preliminary conclusion. At the end of the Lujanian, shortfaced bears seem to have become extinct in South America, approximately $2 \mathrm{ka}$ before they become extinct in North America.

\subsection{Geographic distribution}

\subsubsection{Venezuela}

The fossil record of $A$. wingei in Venezuela is extremely significant because it is the only one in the northern part of South America (Fig. 3). In the future, the short-faced bears' entrance to South America may be documented in the Late Pliocene or Early Pleistocene of this part of the continent.

\subsubsection{Brazil}

Trajano and Ferrarezzi (1994) and Cartelle (1998) suggested that all bears recorded in Brazil correspond to A. wingei, but at least one (skull MHN $\mathrm{s} / \mathrm{n}$ from Minas Gerais, Cartelle, 1994) probably corresponds to A. vetustum (Soibelzon, 2002).

\subsubsection{Uruguay}

Few fossil bear remains occur in Uruguay. Of these few, one (Galy s/n) was assigned to A. tarijense by Soibelzon (2002). Another was assigned to 'Arctodus bonariensis' by Perea and Ubilla (2001), but according to a systematic revision of the Temarctinae subfamily (Soibelzon, 2002; 2004), the fragmentary nature of its record, and the lack of a precise stratigraphic context, it should be considered Arctotherium sp., pending further studies.

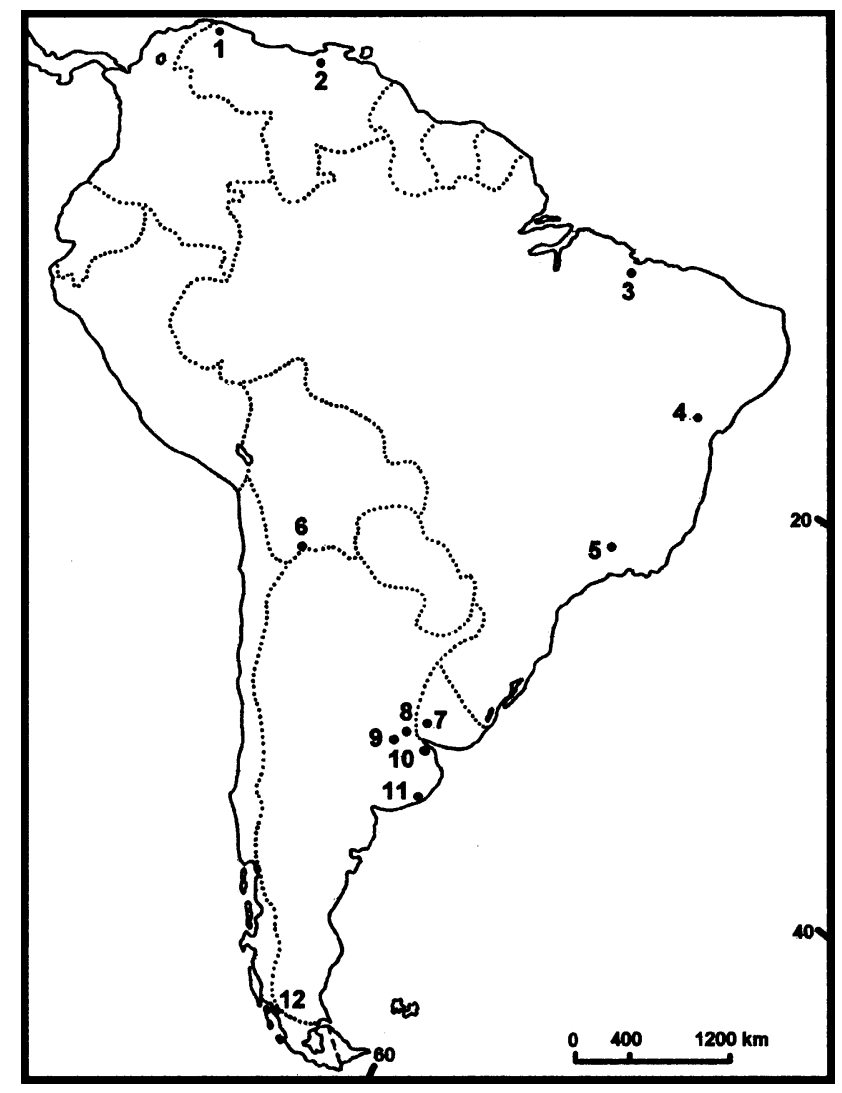

Fig. 3. Map depicting sites with fossil tremarctinaes (modified from Soibelzon, 2002). (1), Falcon state and (2), Monagas state, Venezuela; (3), Ceará state; (4) Bahía state, and (5) Minas Gerais state, Brazil; (6), Tarija Valley, Bolivia; (7), Río Negro County, Uruguay; (8), Entre Ríos province; (9), Santa Fe province; (10), 'Toscas del Río de La Plata,' Buenos Aires and La Plata, Buenos Aires province, Argentina; (11), Marine cliff southeast of Buenos Aires province; (12), Pali Aike National Park and 'Cueva del Milodon,' Chile.

\subsubsection{Bolivia}

All known Bolivian fossil bears come from Tarija Valley. Soibelzon (2002) recognized three species from Bolivia: A. tarijense, A. wingei, and A. angustidens.

\subsubsection{Chile}

In 1900, a portion of femur found in the 'Cueva del Milodón' (Última Esperanza, $52^{\circ} 05^{\prime} 37^{\prime \prime} \mathrm{S}, 69^{\circ} 44^{\prime} 31^{\prime \prime} \mathrm{W}$ ) was referred to Arctotherium sp. (Smith Woodward, 1900). Although the specimen is now lost, the size and morphology reflect those of the femur of Arctotherium, but it cannot be assigned to any particular species. Curiously, this record was ignored in revisions of the South American fossil Tremarctinae (e.g. Kraglievich, 1926; 1934; Kraglievich and Ameghino, 1940; Kurtén, 1967; Berman, 1994; Trajano and Ferrarezzi, 1994). The discovery of an I2 of A. tarijense at 'Cueva de los Chingues' confirms the presence of Arctotherium in southern Patagonia (Prevosti et al., 2003). 


\subsubsection{Argentina}

In the Pampean region of Argentina, all Arctotherium species (except for $A$. wingei) have been recorded. The most complete record comes from Buenos Aires province, with $A$. angustidens, A. vetustum, A. bonariense, A. tarijense, and Arctotherium sp.; some records also appear in Santa Fe, San Luis, and Entre Ríos provinces, but the fossil record in other Argentinean provinces is poor compared with that of Buenos Aires. In Entre Ríos province, only one species, A. vetustum, was recorded. Arctotherium sp. was recorded in San Luis province, and A. tarijense and Arctotherium sp were recorded in Santa Fe province.

\subsection{Biogeographical background}

Florentino Ameghino (1885) suggested a South American origin for the Tremarctinae subfamily on the basis of the erroneous stratigraphic provenance of specimen MACN 1277 (A. vetustum), which he believed to be 'Mesopotamian' in age (Late Miocene). This hypothesis was accepted by Carlos Ameghino (1916), but Merriam et al. (1916), Merriam and Stock (1925), and Kraglievich (1926) placed the stratigraphic provenance of MACN 1277 in doubt and, in turn, questioned Ameghino's $(1885,1906)$ hypothesis.

The Great American Biotic Interchange (GABI; Stehli and Webb, 1985) was considered a dispersion event, though it is difficult to verify a dispersion or vicariance event for the origin of South American short-faced bears. Only one record for Arctotherium occurs in northern South America (A. wingei from the Late Pleistocene and Early Holocene of Venezuela; Linares, pers. comm.), which implies that one of the most plesiomorphic taxa of Arctotherium (Kurtén, 1967; Soibelzon, 2002) was distributed south of the Panamian Isthmus.

The first record of Arctodus in North America is from the Late Pliocene; thus, the cladogenetic event that resulted in Arctodus and Arctotherium should be earlier, perhaps in the Early Pliocene. Since as early as the Late Pliocene, the Panamian Isthmus had emerged, and if we accept the vicariance hypothesis, tremarctine bears must have been recorded in South America at least from that epoch. However, there is no fossil record for bears prior to the Early Pleistocene (Ensenadan) south of the Panamian Isthmus. According to Webb (1991), the most successful holartic families involved in the GABI diversified north of the Panamian Isthmus before the interchange, which suggests that the origin of Arctotherium must be related to a dispersion event rather than a vicariance event.

According to Trajano and Ferrarezzi (1994), a subsequent second event is needed to explain the occurrence of $T$. ornatus in South America. The absence of T. ornatus in the fossil record of either North or South America indicates that this species differentiated during the Holocene from its sister group ( $T$. floridanus).

The fossil record of Arctotherium in South America also indicates that cladogenetic events occurred in intertropical areas. For example, $A$. wingei (exclusively), A. vetustum, $A$. angustidens, and $A$. tarijense have been recorded in those areas.

\section{Conclusions}

First, the Tremarctinae subfamily is distributed exclusively in America, from Alaska to southern Patagonia. The fossil record indicates that the geographic origin of the group was central eastern North America and that the group arrived in South America during the GABI. Second, the Tremarctinae biochron comprises the temporal lapse between Late Miocene $(\sim 7 \mathrm{Ma})$ and recent times. The first record of Ursinae in North America (Blancan I) is younger than the first record of Tremarctinae, in support of Kurtén's (1966) hypothesis with respect to the origin of both subfamilies from Agriotheriinae. The subfamily's first record is in North America during the Hemingfordian (Early Miocene).

Third, the first records of Tremarctinae in North America correspond to the Hemphillian (Plionarctos sp.) and the last to the Rancholabrean (T. floridanus and Arctodus simus). In South America, the first record corresponds to the Ensenadan (A. angustidens) and continues to the present (Tremarctos ornatus), though short-faced bears became extinct during the early Holocene. Thus, the extinction of short-faced bears in both North and South America appears to have been approximately synchronous. Fourth and finally, though Berman (1994) suggested that all shortfaced bear species in South America were recorded during the Ensenadan-Lujanian, the fossil record indicates a species turnover between the Ensenadan and the Bonaerian. During this time, $A$. angustidens was replaced by $A$. tarijense, A. bonaeriense, and A. vetustum (and probably A. wingei), as was suggested by Kraglievich (1934); Kraglievich and Ameghino (1940).

\section{Acknowledgements}

The authors thank Dr. Alejandro Kramartz (MACN), Dr. José F. Bonaparte (MACN), Dr. Webb (FMNH); Dr. Tedford (AMNH), Dr. Andy Currant (NHM, Lenders), Drs. Christian De Muizzon and Francois Pujos (MNHNP), Mr. Daniel Bo (MMPH), Mr. Jorge Petrocelli (MCA), Mr. Jorge Cabañez (Liceo Young), and Drs. Diego Verzi and Mariano Merino (MLP zool) for allowing us to study the material. Dr. Daniel Perea, Dr. Tysson Sacco, and an anonymous reviewer provided valuable suggestions on the manuscript. The authors also thank CONICET; Fundación Antorchas; AMNH Office of Grants and Fellowships; ANPCyT PICT 07-8395; and Secretaría de Ciencia y Técnica de la UNLP for financial support. 


\section{References}

Ameghino, F., 1885. Nuevos restos de mamíferos fósiles oligocenos, recogidos por el profesor Pedro Scalabrini y pertenecientes al Museo provincial de la ciudad de Paraná, Boletín de la Academia de Ciencias de Córdoba 8, 3-207.

Ameghino, F., 1904. Nuevas especies de mamíferos cretáceos y terciarios de la república Argentina. Anales de la Sociedad Científica Argentina $58,225-291$.

Ameghino, F., 1906. Les Formations sédimentaires du crétacé supérieur et du tertiaire de patagonie. Anales del Museo Nacional de Buenos Aires 3 (8), 1-568.

Ameghino, C., 1916. Sobre la dentadura superior de Arctotherium en edad juvenil. Physics 2 (II), 435-437.

Anonymous, 1., 1998. Clovis site on gulf coast yields booty only to waves. Highway project focuses new interest on McFadden Beach. Mammoth Trumpet 13 (4)

Berman, W. D., 1994. Los carnívoros continentales (Mammalia, Carnivora) del Cenozoico en la provincia de Buenos Aires. Thesis, Facultad de Ciencias Naturales y Museo, Universidad Nacional de La Plata, 413 pp. (unpublished). La Plata.

Bidegain, J.C., 1991. Sedimentary development, magnetostratigraphy and sequence of events of late cenozoic in entre rios and surrounding areas in Argentina. Paleogeophysics \& Geodynamics, Department of Geology and Geochemistry. Stockholm Univ., Sweden, 128 pp.

Bidegain, J.C., Martinez, G.A., Osterrieth, M.L., Van Velzen, A., 1998. Magnetoestratigrafía de la secuencia cenozoica de camet (norte de mar del plata), provincia de buenos aires, Actas de las V Jornadas Geológicas y Geofísicas Bonaerenses.

Bond, M., 1999. Quaternary native ungulates of southern South America. A synthesis. In: Rabassa, J., Salemme, M. (Eds.), Quaternary of South America and Antarctic Península 12,177-205.

Cartelle, C., 1994. Tempo passado, Mamíferos do Pleistoceno em Minas Gerais. Palco, Brasil, 131 pp.

Cartelle, C., 1998. Um pequeño urso do pleistoceno final da bahia. Acta Geol. Leopoldensia XXI (46/47), 171-189.

Cione, A.L., Tonni, E.P., 1995. Chronostratigraphy and 'land-mammal ages' in the Cenozoic of southern South America: principles, practices, and the 'Uquian' problem. Journal of Paleontology 69, 135-159.

Cione, A.L., Tonni, E.P, 1999. Bioestratigraphy and chronological scale of uppermost cenozoic in the pampean area, Argentina. In: Rabassa, J., y Salemme, M. (Eds.), Quaternary Vertebrate Paleontology in South America Quaternary of South America and Antarctic Península, vol. 12, pp. 23-51.

Cione, A.L., Tonni, E.P., 2001. Neogene and quaternary continental stratigraphy and mammal evolution. Bolletino della Societ $\times$ Paleontologica Italiana 40 (2), 167-173.

De Salvo, O.E., Ceci, J.H., Dillon, A., 1969. Caracteres geológicos de los depósitos eólicos del pleistoceno superior de junín (provincia de buenos aires). Actas de las Cuartas Jornadas Geológicas Argentinas I, 269-292.

Gervais, P., 1855. Recherches sur les mamiféres fossiles de 1'Amérique du Sud. En: Expédition dans les parties centrales de 1'Amérique du Sud, de Rio de Janeiro á Lima, et de Lima au Para; exécuté par ordre du Gouvenement francais pendant les années 1843 á 1847 sous la direction de F. Castelnau, Castelnau, F. (Dir.). Zoologie 7: 1-63, láms. 4-13. P. Bertrand, Paris.

Gillette, D.D., 1996. Utah`s Wildlife in the Ice Age. Survey Notes 28 (3), 58.

Gobetz, K.G., Martin, L.D., 2001. An exceptionally large short-faced bear (Arctodus simus) from the late pleistocene (?)/Early holocene of kansas. Current Research in the Pleistocene 18, 97-99.

Isla, F.I., Rutter, N.W., Schnack, E.J., Zárate, M.A., 2000. La transgresión belgranense en buenos aires, una revisión a cien años de su definición, Asociación Geológica Argentina, Serie D, vol. 4. Publicación Especial $\mathrm{N}^{\circ}$. 4, pp. 3-14.
Kraglievich, L., 1926. Los arctoterios norteamericanos (Tremarctotherium, n. gen.) en relación con los de Sud América. Anales del Museo Nacional de Historia Natural 'Bernardino Rivadavia' 34 (56), 1-16.

Kraglievich, L., 1934. La antigüedad pliocena de las faunas de monte hermoso y chapadmalal, deducidas de su comparación con las que le precedieron y sucedieron, Imprenta 'El Siglo Ilustrado', pp. 1-136.

Kraglievich, L., Ameghino, C., 1940. Los úrsidos extinguidos de sud América. In: Kraglievich, L. (Ed.), Obras de Paleontología y Geología Talleres de Impresiones Oficiales, vol. 3, pp. 557-627.

Kurtén, B., 1966. Pleistocene bears of North America: 1 genus tremarctos, spectacled bears. Acta Zoologica Fennica 115, 1-120.

Kurtén, B., 1967. Pleistocene bears of North America: 2 genus arctodus, short faced bears. Acta Zoologica Fennica 117, 1-60.

Kurtén, B., Anderson, E., 1980. Pleistocene Mammals of North America. Columbia University Press, New York, 442 pp.

MacFadden, B., 2000. Middle pleistocene climate change recorded in fossil mammal teeth from tarija, bolivia, and upper limit of the ensenadan land mammal age. Quaternary Research 54, 121-131.

Merriam, J.C., Stock, C., 1925. Relationships and structure of the short-faced bear, Arctotherium, from the pleistocene of California. Contributions to palaeontology from the carnegie institution of Washington, Papers Concerning the Palaeontology of the Pleistocene of California and the Tertiary of Oregon, Part 1, pp. $1-35$.

Merriam, J.C., Stock, C., Moody, C.L., 1916. An American Pliocene Bear. Univ. Calif. Pub. Bull. Dept. Geol. 10, 87-109.

Pardiñas, U.F.J., Gelfo, J.N., San Cristobal, J., Cione, A.L., Tonni, E.P., 1996. Una tafocenosis de organismos marinos y continentales en el Pleistoceno superior en el sur de la provincia de buenos aires. Actas del XIII Congreso Geológico Argentino y III Congreso de Exploración de Hidrocarburos 5, 95-111.

Pardiñas, U.F.J., Tonni, E.P., Figini, A., 1998. Camet Norte: diversidad faunística próxima al Ultimo máximo glacial en el sudeste de la provincia de buenos aires (Argentina). Actas del X Congreso Latinoamericano de Geología y VI Congreso Nacional de Geología Económica 1, 257-262.

Perea, D., Ubilla, M., 1983. Arctodus pamparus (Amegh) (Mammalia, Ursidae) en sedimentos lujanenses del dep. Río negro, uruguay, Resúmenes y Comunicaciones de las Jornadas de Ciencias Naturales 1983.

Perea, D., Ubilla, M.. 2001. South American fossil bears (Ursidae, Tremarctinae): a phylogenetic and paleoecologic approach. Actas XI Congr. Latinoamer. Geol. III Congr. Uruguayo Geol. (CDROM).

Prevosti, F.J., Soibelzon, L.H., Prieto, A., San Roman, M., Morello, F., 2003. The southernmost bear: Pararctotherium (Carnivora, Ursidae, Tremarctinae) in the latest pleistocene of southern patagonia, chile. Journal of Vertebrate Paleontology 23 (3), 709-712.

San Roman, M.B., Morello, F.R., Prieto, A.I., 2000. Cueva de los Chingues (Parque Nacional Pali Aike), Magallanes, Chile. Historia natural y cultural I. Anales del Instituto de la Patagonia Serie Ciencias Historicas $28,125-146$.

Smith Woodward, L.L.D., F.Z.S., 1900. On some remains of Grypotherium (Neomylodon) listai and associated mammals from cavern near consuelo cove, last hope inlet, patagonia. Proc. Zool. Soc. London I, 64-75 (Pl V-IX).

Soibelzon, L. H., 2002. Los Ursidae (Carnivora, Fissipedia) fósiles de la República Argentina. Aspectos Sistemáticos y Paleoecológicos. Thesis, Facultad de Ciencias Naturales y Museo, Universidad Nacional de La Plata (Unpublished). 239 pp. +42 Figuras +16 Tablas. La Plata.

Soibelzon, L.H., 2004. Revisión sistemática de los tremarctinae (Carnivora, Ursidae) fósiles de América del sur. Revista Museo Argentino de Ciencias Naturales 6 (1), 107-133. 
Soibelzon, L.H., Soibelzon, E., 1999. A new record of Arctotherium bonariensis (Ursidae, Tremarctinae) from buenos aires province, Argentina. Ameghiniana 36 (4) (Suplemento).

Soibelzon, L.H., Gelfo, J., Pascuali, R., 1999. Bioestratigrafía del valle del río arrecifes, prov. de buenos aires, Argentina. Actas del XIV Congreso Geológico Argentino I, 381-384.

Soibelzon, L.H., Tonni, E.P., Bond, M., 2001. Arctotherium latidens (Ursidae, Tremarctinae) en el Pleistoceno de la Provincia de Buenos Aires, Argentina.Comentarios Sistemáticos y Bioestratigráficos. Actas del Congreso Latinoamericano de Geología (CD-ROM).

Stehli, F.G., Webb, S.D. (Eds.), 1985. The Great American Biotic Interchange. Plenum Press, New York.

Talbot, S.L., Shields, G.F., 1996. A phylogeny of the bears (Ursidae) inferred from complete sequences of three mitocondrial genes. Molecular Phylogenetics and Evolution 5 (3), 567-575.

Tedford, R.H., Martin, J., 2001. Plionarctos, a Tremarctinae bear (Ursidae: Carnivora) from western North America. Journal of Vertebrate Paleontology 21 (2), 311-321.

Tonni, E.P., Cione, A.L. (Eds.), 1999. Quaternary vertebrate paleontology in South America, Quaternary of South America and Antarctic Peninsula, Roterdam 12, 1-310.

Tonni, E.P., Fidalgo, F., 1982. Geología y paleontología de los sedimentos del pleistoceno en el area de punta hermengo (Miramar, prov. de buenos aires, rep. Argentina): aspectos paleoclimáticos. Ameghiniana 19 (1-2), 79-108.
Tonni, E.P., Alberdi, M.T., Prado, J.L., Brago, M.S., Cione, A.L., 1992. Change of mammal assemblages in the pampean region (Argentina) and their relation with the plio-pleistocene boundary. Palaeogeography, Palaeoclimatology, Palaeoecology 95, 179-194.

Tonni, E.P., Pardiñas, U.F.J., Verzi, D.H., Noriega, J.I., Scaglia, O., Dondas, A., 1998. Microvertebrados pleistocénicos del sudeste de la provincia de buenos aires (Argentina): bioestratigrafía y paleoambientes. Actas de las V Jornadas Geológicas y Geofísicas Bonaerenses, 73-83.

Tonni, E.P., Nabel, P., Cione, A.L., Etchichury, M., Tofalo, R., ScillatoYané, G., San Cristóbal, J., Carlini, A., Vargas, D., 1999. The ensenada and buenos aires formations (Pleistocene) in a quarry near la plata, Argentina. Joural of South American Earth Sciences 12, 273-291.

Trajano, E., Ferrarezzi, H., 1994. A fossil bear from northeastern Brazil, with a phylogenetic analysis of the South American extinct Tremarctinae (Ursidae). Journal of Vertebrate Paleontology 14 (4), 552-561.

Ubilla, M., Perea, D., 1999. Quaternary vertebrates of uruguay: a biostratigraphic, biogeographic and climatic overview. In: Tonni, E.P., Cione, A.L. (Eds.), Quaternary Vertebrate Paleontology in South America. Quaternary of South America and Antarctic Peninsula, vol 12, pp. 75-90.

Webb, S.D., 1991. Ecogeography and the great american interchange. Paleobiology 17 (3), 266-280.

Winge, H., 1895-1896. Jordfundne og nulevende rovdyr (Carnivora) fra lagoa Santa, Minas Geraes, Brasilien. E Museo Lundii 2 (4), 1-103. 